\title{
Critical State of Sand Matrix Soils
}

\author{
Aminaton Marto, ${ }^{1}$ Choy Soon Tan, ${ }^{1}$ Ahmad Mahir Makhtar, ${ }^{1}$ and Tiong Kung Leong ${ }^{2}$ \\ ${ }^{1}$ Faculty of Civil Engineering, Construction Research Centre, Universiti Teknologi Malaysia (UTM), \\ 81310 Johor Bahru, Johor, Malaysia \\ ${ }^{2}$ Faculty of Management and Human Resource Development, Universiti Teknologi Malaysia (UTM), \\ 81310 Johor Bahru, Johor, Malaysia \\ Correspondence should be addressed to Choy Soon Tan; cstan8@live.utm.my
}

Received 10 January 2014; Accepted 16 February 2014; Published 16 March 2014

Academic Editors: J. Lian and J. R. Rabuñal

Copyright (C) 2014 Aminaton Marto et al. This is an open access article distributed under the Creative Commons Attribution License, which permits unrestricted use, distribution, and reproduction in any medium, provided the original work is properly cited.

The Critical State Soil Mechanic (CSSM) is a globally recognised framework while the critical states for sand and clay are both well established. Nevertheless, the development of the critical state of sand matrix soils is lacking. This paper discusses the development of critical state lines and corresponding critical state parameters for the investigated material, sand matrix soils using sand-kaolin mixtures. The output of this paper can be used as an interpretation framework for the research on liquefaction susceptibility of sand matrix soils in the future. The strain controlled triaxial test apparatus was used to provide the monotonic loading onto the reconstituted soil specimens. All tested soils were subjected to isotropic consolidation and sheared under undrained condition until critical state was ascertain. Based on the results of 32 test specimens, the critical state lines for eight different sand matrix soils were developed together with the corresponding values of critical state parameters, $M, \lambda$, and $\Gamma$. The range of the value of $M$, $\lambda$, and $\Gamma$ is $0.803-0.998,0.144-0.248$, and $1.727-2.279$, respectively. These values are comparable to the critical state parameters of river sand and kaolin clay. However, the relationship between fines percentages and these critical state parameters is too scattered to be correlated.

\section{Introduction}

Recent field evidences of ground failure in sand with limiting percentages of fines during strong earthquakes have highlighted the need to better characterize the stress-strain behaviour of saturated soils in a broader range, from pure sand to sand matrix soils. Although the recent study trend focuses more on the investigation of sand with limiting percentages of fines, the situation is more worsening when there is still no clear conclusion that could be drawn at this moment to describe the roles of fines in liquefaction susceptibility of sand matrix soils. In the absence of a fundamental understanding of the seismic behaviour of sand matrix soils, the usability of the currently used liquefaction susceptibility assessment criteria, the Modified Chinese Criteria that solely relies on the interpretation of few earthquake events, is actually questionable [1-3].

The shear strength and the deformation behaviour of soil are so depended to the combination of changes in volume and confining stress. But the research approach in geotechnical field is to lump together those related postreconnaissance data to formulate new empirical assessment criteria, without capturing their true characteristic through fundamental soil mechanics interpretation. Without implicitly considering the fundamental basis of soil mechanics, applicability of these empirical guidelines which is nonuniversally applicable is arguable. These empirical data only provide limited insight to existing state of art.

The stress-strain behaviour of soils could be either stimulated through constitute models or interpreted within classical plasticity models such as Mohr-Coulomb. Among these models, Critical State Soil Mechanic (CSSM) developed by Schofield and Wroth [4] is the most robust framework to explain the fundamental behaviour of different soil materials. The fact that a loose soil is compressible while a dense soil is dilatants is in general agreement. Density well presented the soil behaviour especially for granular soils. Therefore, CSSM is a powerful tool able to explain the behaviour of soil 
TABLE 1: Overall developments of CSSM with respect to soil liquefaction.

\begin{tabular}{|c|c|c|}
\hline Year & Researchers & Developments \\
\hline 1940 & Casagrande [11] & $\begin{array}{l}\text { Introduced critical void ratio, the same void ratio where contracted } \\
\text { loose soil and dilated dense soil approach after sheared to large strains }\end{array}$ \\
\hline 1956 & Taylor [12] & Showed experimentally that dilatancy is stress dependent \\
\hline 1958 & Roscoe et al. [13] & $\begin{array}{l}\text { Defined critical state as the ultimate state at which a soil continues to } \\
\text { deform at constant stress and constant void ratio }\end{array}$ \\
\hline 1968 & Schofield and Wroth [4] & $\begin{array}{l}\text { Brought together stress-dependent strength and dilatancy to introduce } \\
\text { critical state soil mechanics with Cam-Clay model }\end{array}$ \\
\hline 1969 & Castro [14] & $\begin{array}{l}\text { Observed three different types of stress-strain behaviour (liquefaction, } \\
\text { limited liquefaction, and dilation) in monotonic loading tests }\end{array}$ \\
\hline 1975 & Casagrande [15] & $\begin{array}{l}\text { Developed steady state line from both drained and undrained tests and } \\
\text { noticed that dense sand can be liquefying under sufficient high load }\end{array}$ \\
\hline 1981 & Poulos [16] & $\begin{array}{l}\text { Formalised the concept of steady state of deformation (continually } \\
\text { deformation under four constant conditions: volume, normal effective } \\
\text { stress, shear stress, and velocity) }\end{array}$ \\
\hline 1985 & Poulos et al. [17] & $\begin{array}{l}\text { Recognised that steady-state line is useful for identifying the } \\
\text { susceptibility of flow liquefaction }\end{array}$ \\
\hline 1985 & Been and Jefferies [18] & $\begin{array}{l}\text { Proposed state parameter, the void ratio difference between current state } \\
\text { and critical state at same mean stress }\end{array}$ \\
\hline 1991 & Been et al. [19] & $\begin{array}{l}\text { Showed that critical state and steady state of sands are equivalent and } \\
\text { independent of stress path, sample preparation method, and initial } \\
\text { density }\end{array}$ \\
\hline
\end{tabular}

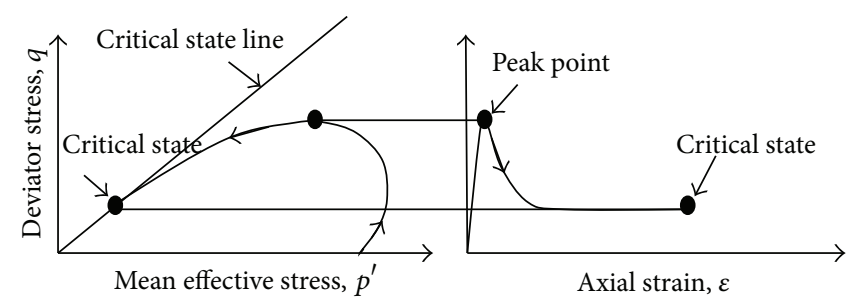

FIGURE 1: Idealised behaviour of loose particular soil in undrained triaxial shear [10].

at various density states. It is a globally recognised framework that the critical states for sand and clay are both well established. Nevertheless, the development of the critical state of sand matrix soils is lacking.

Moreover, CSSM also rooted the basic theoretical framework of soil liquefaction, yet most available findings within the current literature were outside this critical state context. Table 1 summarizes the overall developments of critical CSSM with respect to soil liquefaction study. This paper aims to discuss the development of the critical state line and corresponded critical state parameters for the investigated material, sand matrix soils using sand-kaolin mixtures. The output of this paper will be used as an interpretation framework for the research of liquefaction susceptibility of sand matrix soils in future.

\section{The Critical State of Sand}

To date, quite a number of granular soils have been tested to establish for their critical state. Figure 1 shows the undrained behaviour of loose sand under triaxial testing. The steady state is exactly representing the critical void ratio under
CSSM interpretation. The critical state line (CSL) shows the unique relationship between the deviator stress $(q)$, the mean normal effective stress $\left(p^{\prime}\right)$, and the specific volume $(\nu)$. The relationship is as follows:

$$
\begin{gathered}
q_{f}=M p_{f}^{\prime} \\
v_{f}=\Gamma-\lambda \ln p_{f}^{\prime}
\end{gathered}
$$

in which the subscripts " $f$ " denote the ultimate failure at the critical states; $M$ denote the critical stress ratio; $\lambda$ denote the gradient of the critical state line; $\Gamma$ denote the intercept of the critical state line. The parameters of $M, \lambda$, and $\Gamma$ are regarded as constants for a particular soil and the values for some typical soils are given in Table 2.

Jefferies and Been [5] had summarised some of the important results as shown in Table 3. In fact, the critical state line is not always in its linear relationship especially at stresses higher than $1000 \mathrm{kPa}$. However, the range of interest in engineering community is lower than $500 \mathrm{kPa}$; it is true to treat the critical state line in linear form.

Several researchers try to correlate index properties of granular soils with critical state parameter including fines 
TABle 2: Critical state parameters of some soil types [20].

\begin{tabular}{|c|c|c|c|c|c|c|c|c|}
\hline Soil Indexes & LL & $\mathrm{PL}$ & $\lambda$ & $\Gamma$ & $N$ & $M$ & $\phi^{\prime}$ & $\kappa / \lambda$ \\
\hline \multicolumn{9}{|l|}{ Fine-grained clay soils } \\
\hline London clay & 75 & 30 & 0.16 & 2.45 & 2.68 & 0.89 & $23^{\circ}$ & 0.39 \\
\hline Kaolin clay & 65 & 15 & 0.19 & 3.14 & 3.26 & 1.00 & $25^{\circ}$ & 0.26 \\
\hline Glacial till & 35 & 17 & 0.09 & 1.81 & 1.98 & 1.18 & $29^{\circ}$ & 0.16 \\
\hline \multicolumn{9}{|l|}{ Coarse-grained soils } \\
\hline River sand & & & 0.16 & 2.99 & 3.17 & 1.28 & $32^{\circ}$ & 0.09 \\
\hline Decomposed granite & & & 0.09 & 2.04 & 2.17 & 1.59 & $39^{\circ}$ & 0.06 \\
\hline Carbonate sand & & & 0.34 & 4.35 & 4.80 & 1.65 & $40^{\circ}$ & 0.01 \\
\hline
\end{tabular}

TABLE 3: Critical state properties of some soils (after Jefferies and Been [5]).

\begin{tabular}{lccccc}
\hline Soils & Fines (\%) & $e_{\max }$ & $e_{\min }$ & $\Gamma$ & $\lambda_{10}$ \\
\hline Castro sand B & 0 & 0.840 & 0.500 & 0.791 & 0.041 \\
Castro sand C & 0 & 0.990 & 0.660 & 0.988 & 0.038 \\
Monterey & 0 & 0.820 & 0.540 & 0.878 & 0.029 \\
Nevada & 7.5 & 0.887 & 0.511 & 0.910 & 0.045 \\
Ottawa & 0 & 0.790 & 0.490 & 0.754 & 0.028 \\
Toyoura & 0 & 0.873 & 0.656 & 1.000 & 0.039 \\
Erksak 330/0.7 & 0.7 & 0.747 & 0.521 & 0.816 & 1.29 \\
Erksak 320/1 & 1 & 0.808 & 0.614 & 0.875 & 1.13 \\
Erksak 355/3 & 3 & 0.963 & 0.525 & 0.848 & 0.043 \\
Chek Lap Kok & 0.5 & 0.682 & 0.411 & 0.905 & 0.054 \\
\hline
\end{tabular}

content [6], void ratio [7], and liquidity index [8]. However, findings show that these index properties on their own only give scatter relationship to be correlated with critical state parameters. These findings therefore are too irrelevant to be practically used. However the intrinsic properties of sand including grain size distribution do actually show their significance influence to the critical state line. Clean sand with rounded grains would have a lower value of $\lambda$ ( $\lambda$ about $0.03)$ compared to silty sands with angular shape $(\lambda$ about $0.2)$.

\section{Experiment Testing}

In order to establish the critical state line and the critical state parameters for the investigated material, monotonic triaxial compression tests have been performed. The discussion in this paper based on a total of 32 triaxial tests was carried out on sand-kaolin mixtures at several percentages by weight. The parent sand is uniformly graded medium sand (SP) with specific gravity of 2.63. It was obtained from a river in Johor Bahru, Malaysia. In order to obtain clean sand, it was first rinsed with water to remove impurities before proceeding with the sieve analysis. White kaolin with a specific gravity of 2.62, plastic limit of 38, and liquid limit of 25, manufactured by Kaolin (Malaysia) Sdn Bhd, were added to parent sand to create sand matrix soils with various fines percentages by weight. The index properties of the tested sand matrix soils are presented in Table 4 . The specific gravity of all sand matrix soils is therefore also as 2.63. Based on the criteria

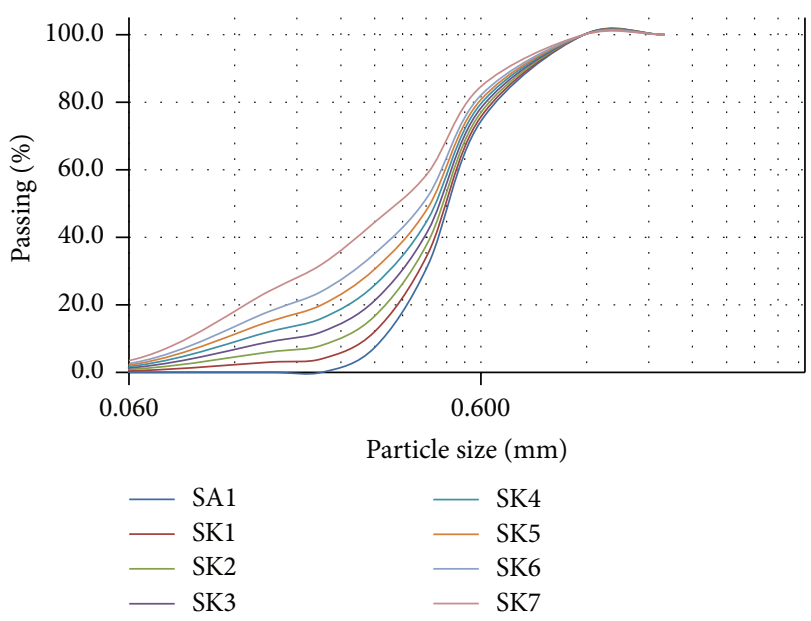

Figure 2: Particle size distribution of the tested soils.

of coefficient of uniformity $(\mathrm{Cu})$ and coefficient of curvature (Cc) in Unified Soil Classification System, all of the sand matrix soils are classified under uniformly graded soils (SP). Particle size distribution is shown in Figure 2.

The testing conditions were set constantly to increase the precision. All tested specimens have an approximately $100 \mathrm{~mm}$ height by $50 \mathrm{~mm}$ diameter cylindrical size. Monotonic triaxial compression tests were carried out on strain controlled triaxial apparatus under undrained condition. The specimens were prepared under dry deposition methods to 
TABLE 4: Compositional characteristic of tested sand matrix soils.

\begin{tabular}{|c|c|c|c|c|c|c|c|c|}
\hline \multirow{2}{*}{ Tested soils } & \multicolumn{2}{|c|}{ Weight percentages (\%) } & \multicolumn{2}{|c|}{ Density $\left(\mathrm{Mg} \mathrm{m}^{-3}\right)$} & \multicolumn{2}{|c|}{ Void ratio } & \multicolumn{2}{|c|}{ Grading } \\
\hline & Sand & kaolin & Min & Max & Min & Max & $\mathrm{Cu}$ & $\mathrm{Cc}$ \\
\hline SA1 & 100 & 0 & 1.37 & 1.59 & 0.920 & 0.649 & 4.1 & 1.5 \\
\hline SK1 & 95 & 5 & 1.39 & 1.66 & 0.894 & 0.582 & 4.8 & 1.7 \\
\hline SK2 & 90 & 10 & 1.41 & 1.70 & 0.867 & 0.550 & 5.0 & 1.2 \\
\hline SK3 & 85 & 15 & 1.43 & 1.76 & 0.841 & 0.491 & 5.4 & 1.2 \\
\hline SK 4 & 80 & 20 & 1.45 & 1.80 & 0.815 & 0.462 & 5.7 & 0.8 \\
\hline SK5 & 75 & 25 & 1.47 & 1.87 & 0.788 & 0.409 & 5.7 & 0.4 \\
\hline SK6 & 70 & 30 & 1.39 & 1.76 & 0.894 & 0.491 & 5.4 & 0.3 \\
\hline SK7 & 60 & 40 & 1.28 & 1.63 & 1.051 & 0.615 & 4.6 & 0.3 \\
\hline
\end{tabular}

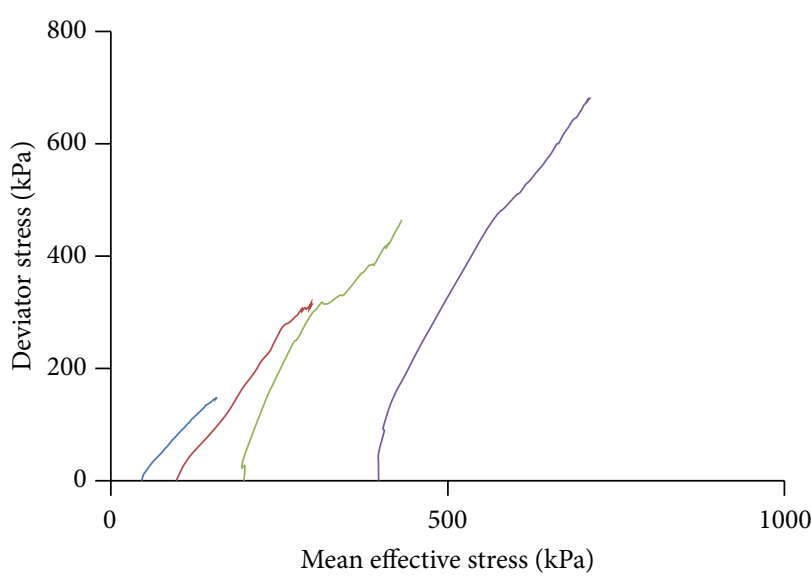

(a)

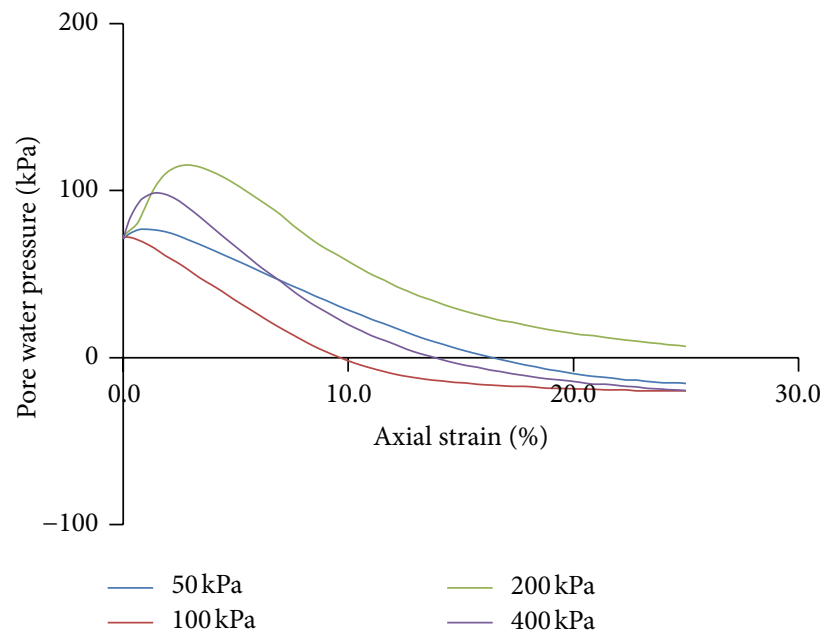

(c)

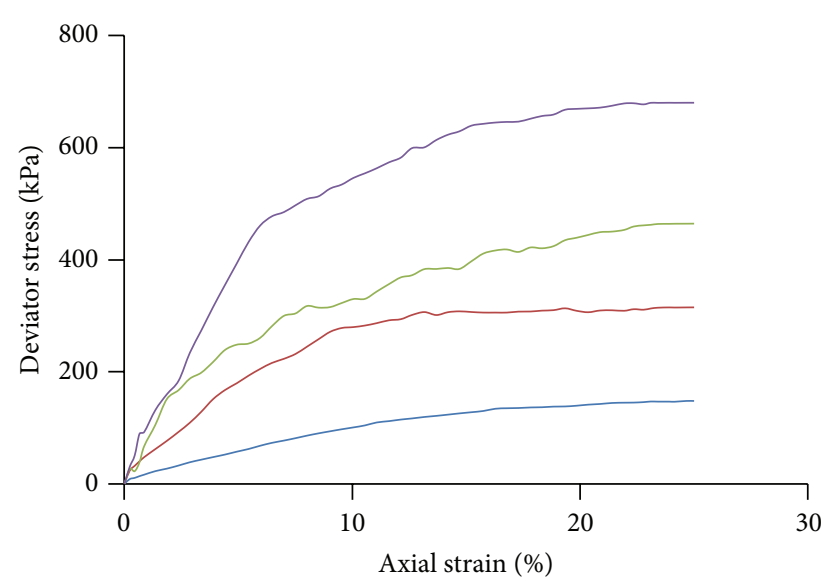

(b)

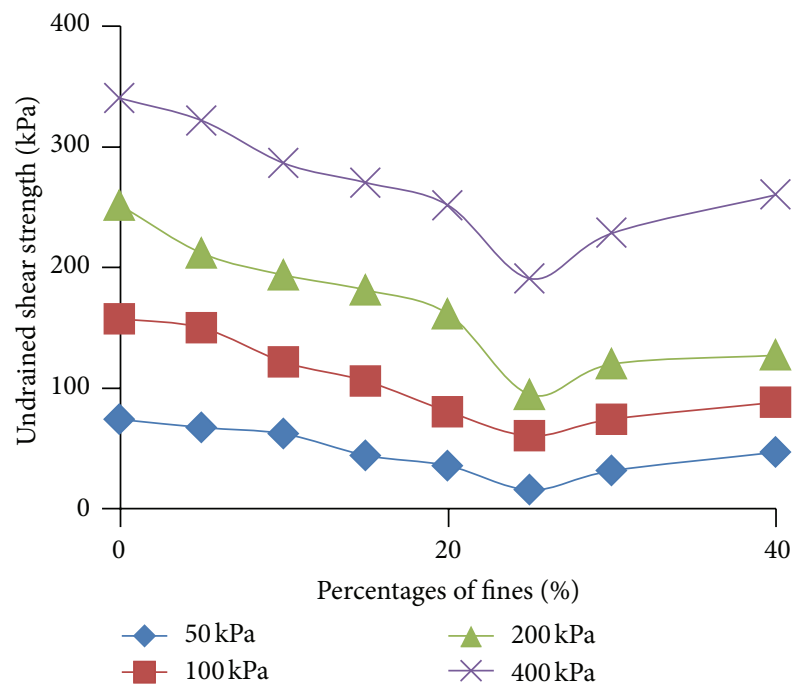

(d)

FIGURE 3: (a) Stress path; (b) peak deviator stress; (c) pore pressure developments; (d) undrained shear strength of tested sand matrix soils.

a relative density of $50 \%$. The mould was gently tapped to densify the sand to the required void ratio. The specimens were saturated by being initially flushed with deaired water and followed by increasing the back pressure of $100 \mathrm{kPa}$. An effective stress of approximately $10 \mathrm{kPa}$ was maintained on the specimen during back pressure saturation. To enhance the consistency of the testing condition, the test was terminated if the specimen could not reach a $B$ value of at least 0.96 at this stage. The strain rate of the shearing process is $0.2 \mathrm{~mm} / \mathrm{min}$. The specimens were then isotropically consolidated at various effective confining stresses of $50 \mathrm{kPa}, 100 \mathrm{kpa}$, $200 \mathrm{kPa}$, and $400 \mathrm{kPa}$. The moisture content was measured 


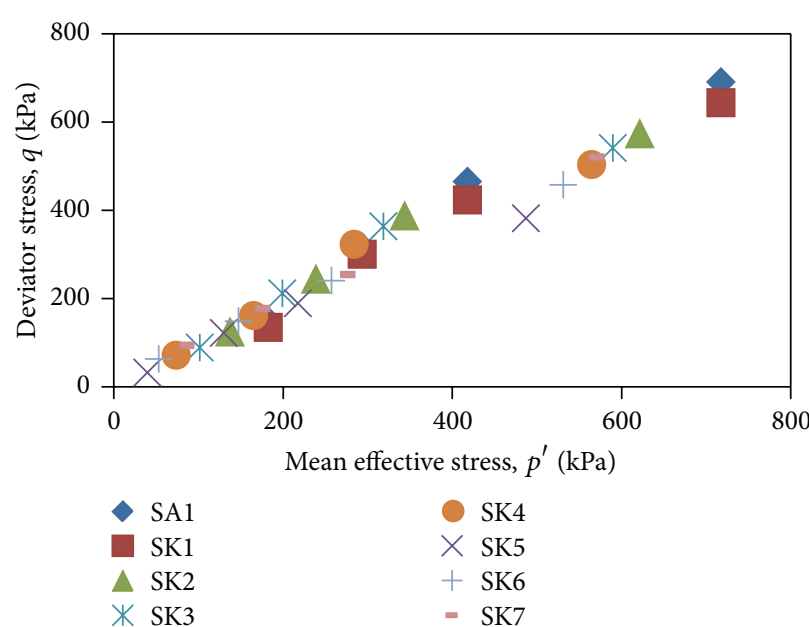

(a) Critical state line in $q-p^{\prime}$ space

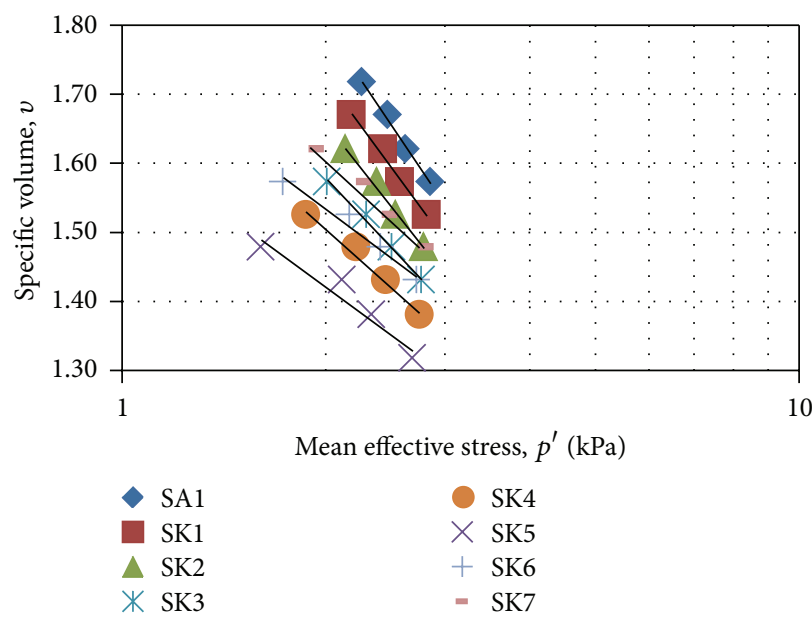

(c) Critical sate line in log form

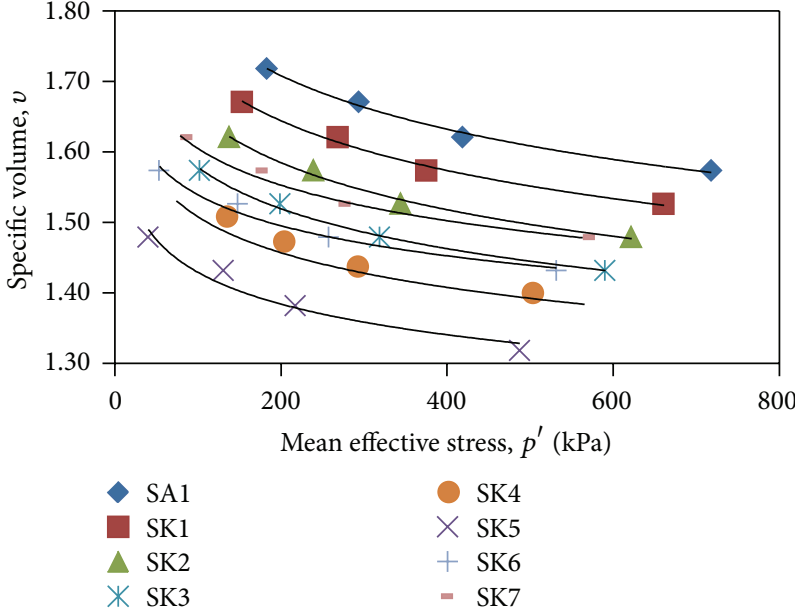

(b) Critical state line in $v$ - $p^{\prime}$ space

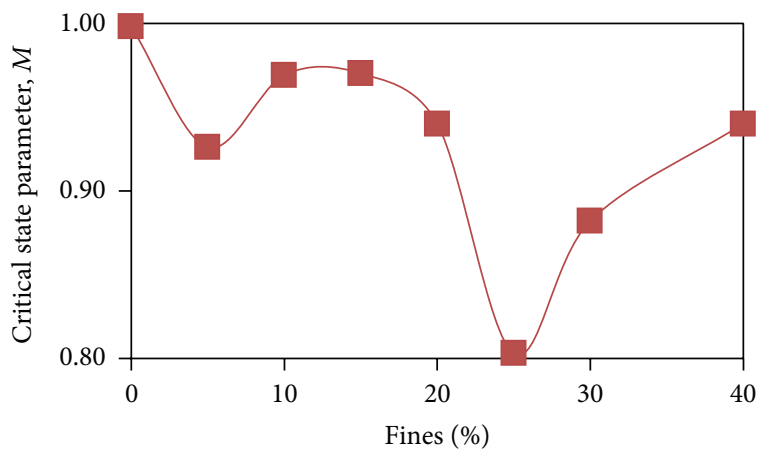

(d) Critical state parameters

FIGURE 4: Critical state line and critical state parameters of tested sand matrix soils.

at the end of monotonic tests to enable the specific volume at particular mean normal effective stress to be backed calculated.

\section{Results and Discussion}

Figure 3(a) shows the typical stress path of the tested soils performed in this study, particularly the clean sand specimen (SA1). The peak deviator stress is correspondingly increasing at higher effective confining stress as shown in Figure 3(b). It can be observed in Figure 3(c) that the dense specimens (at relative density of $50 \%$ ) develop negative pore pressure and thus increase the final shear strength. In fact, most researchers prefer to use loose state specimen in establishing the critical state line because of the noticeable peak strength and residue state. However, the existence of quasi-steady state is so confusing and may lead to conservative conclusion. Hence, a dense specimen was considered in this study. Figure 3(d) shows the peak deviator stress of all 32 monotonic undrained triaxial testings. The hyperbolic curve and the noticeable drop at $25 \%$ of kaolin added in sand have been justified in companion paper [9]. The additional of fines will initially facilitate grain separation. At the point of threshold fines content where the fines already fully occupy the interstitial space between the sand grains, it forces a return of the sand matrix soils to far less compressible behaviour.

Based on the results of monotonic undrained triaxial testing, the critical state lines of 8 different sand matrix soils are plotted in two different spaces. These critical state lines are parallel to one another. In fact, the straight line through the origin in Figure 4(a) ( $q-p^{\prime}$ space) and the curved line in Figure 4(b) (v-p space) are corresponded, when transforming the $v-p^{\prime}$ space into log form as in Figure 4(c); the values of $\Gamma$ and $\lambda$ could be obtained. Table 5 summarised the critical state parameters of the tested soils in this study. The range of the value of $M, \lambda$, and $\Gamma$ is $0.803-0.998,0.144-0.248$, and $1.727-2.279$, respectively. These values are comparable to the critical state parameters of river sand and kaolin clay as shown in Table 2. To compare these critical state parameters at different percentages of fines, for example, Figure 4(d) was 
TABLE 5: The critical state parameters.

\begin{tabular}{lccc}
\hline Soils & $M$ & $\Gamma$ & $\lambda$ \\
\hline SA1 & 0.998 & 2.279 & 0.248 \\
SK1 & 0.926 & 2.180 & 0.232 \\
SK2 & 0.969 & 2.094 & 0.221 \\
SK3 & 0.970 & 1.956 & 0.189 \\
SK4 & 0.940 & 1.840 & 0.166 \\
SK5 & 0.803 & 1.727 & 0.148 \\
SK6 & 0.882 & 1.829 & 0.144 \\
SK7 & 0.940 & 1.944 & 0.269 \\
\hline
\end{tabular}

plotted, particularly the value of $M$ across fines percentages. However, there is not an apparent relationship that could be drawn between fines percentages and these critical state parameters. The relationship between fines percentages and these critical state parameters are too scattered to be correlated. In addition, other compositional characteristics including both coefficient of curvature and uniformity, limiting void ratio, and void ratio range are also able to uniquely describe the behaviour of sand matrix soils of different fines percentages. The general indexes that have been usually used to describe the compositional characteristics are not sufficient enough to give good correlations in quantifying the trends of critical state parameters across different percentages of fines added in parent sand. Loosely speaking, the plastic behaviour due to the presence of kaolin, as the plastic fines, is a very potential cause for such variation. The plasticity of higher percentages of kaolin existing within parent sand should have higher values compared to lower percentages. Although it is important to find out which intrinsic factor is actually corresponding to such changes, it is beyond the aims and scope of this paper. Therefore, more researches are warranted in future.

\section{Conclusion}

An experimental study with undrained monotonic triaxial compression test has been conducted on sand-kaolin mixtures (sand matrix soils) and the results were used to establish the critical state of the soils together with corresponding critical state parameters. Based on the results, the following conclusions are achieved.

(1) The range of the value of $M, \lambda$, and $\Gamma$ is $0.803-0.998$, $0.144-0.248$, and $1.727-2.279$, respectively.

(2) Neither the fines percentages nor other corresponding compositional characteristics are adequate to be correlated with the critical state parameters of sand matrix soils.

(3) More researches are warranted in future to find out which intrinsic factor significantly contributes to the changes to the critical state parameters of sand matrix soils across different fines percentages.

\section{Conflict of Interests}

The authors declare that there is no conflict of interests regarding the publication of this paper.

\section{Acknowledgments}

The authors gratefully acknowledged the financial support by the Ministry of Education, Malaysia, (MOE) under the Fundamental Research Grant Scheme (Vot 4F316) and also the Universiti Teknologi Malaysia (UTM) through Zamalah program in undertaking the research to publish the results. The support from the Construction Research Centre and Construction Research Alliance, UTM is also acknowledged.

\section{References}

[1] R. W. Boulanger and I. M. Idriss, "Liquefaction susceptibility criteria for silts and clays," Journal of Geotechnical and Geoenvironmental Engineering, vol. 132, no. 11, pp. 1413-1426, 2006.

[2] S. Prakash and V. K. Puri, "Recent advances in liquefaction of fine grained soils," in Proceedings of the 5th International Conference on Recent Advances in Geotechnical Earthquake Engineering and Soil Dynamics, San Diego, Calif, USA, 2010.

[3] A. Marto and C. S. Tan, "Short review on liquefaction susceptibility," International Journal of Engineering Research and Applications, vol. 2, pp. 2115-2119, 2012.

[4] A. Schofield and C. P. Wroth, Critical State Soil Mechanics, McGrawHill, London, UK, 1968.

[5] M. Jefferies and K. Been, Soil Liquefaction: A Critical State Approach, Taylor \& Francis, London, UK, 2006.

[6] C. A. Stamatopoulos, "An experimental study of the liquefaction strength of silty sands in terms of the state parameter," Soil Dynamics and Earthquake Engineering, vol. 30, no. 8, pp. 662678, 2010.

[7] A. Papadopoulou and T. Tika, "The effect of fines on critical state and liquefaction resistance characteristics of non-plastic silty sands," Soils and Foundations, vol. 48, no. 5, pp. 713-725, 2008.

[8] B. Muhunthan and D. L. Worthen, "Critical state framework for liquefaction of fine grained soils," Engineering Geology, vol. 117, no. 1-2, pp. 2-11, 2011.

[9] A. Marto, C. S. Tan, A. M. Makhtar, N. Z. M. Yunus, and A. Amaludin, "Undrained shear strength of sand plastic fines mixtures," Malaysian Journal of Civil Engineering, vol. 25, no. 2, pp. 189-199, 2013.

[10] K. Been and M. Jefferies, "Stress-dilatancy in very loose sand," Canadian Geotechnical Journal, vol. 41, no. 5, pp. 972-989, 2004.

[11] A. Casagrande, "Characteristics of cohesionless soils affecting the stability of slopes and earth fills," Contributions to Soils Mechanics, pp. 1925-1940, 1940.

[12] D. W. Taylor, Fundamentals of Soil Mechanics, John Wiley \& Sons, London, UK, 1956.

[13] K. H. Roscoe, A. Schofield, and C. P. Wroth, "On the yielding of soils," Geotechnique, vol. 8, no. 1, pp. 22-53, 1958.

[14] G. Castro, Liquefaction of sands [Ph.D. thesis], Harvard University Cambridge, 1969.

[15] A. Casagrande, "Liquefaction and cyclic deformation of sands: a critical review," in Proceedings of the 5th Panamerican Conference on Soil Mechanics and Foundation Engineering, Buenos Aires, Argentina, 1975. 
[16] S. J. Poulos, "The steady state of deformation," Journal of the Geotechnical Engineering Division, vol. 107, no. 5, pp. 553-562, 1981.

[17] S. J. Poulos, G. Castro, and J. W. France, "Liquefaction evaluation procedure," Journal of Geotechnical Engineering, vol. 111, no. 6, pp. 772-792, 1985.

[18] K. Been and M. G. Jefferies, "State parameter for sands," International Journal of Rock Mechanics and Mining Sciences and Geomechanics Abstracts, vol. 22, no. 6, 1985.

[19] K. Been, M. G. Jefferies, and J. Hachey, "The critical state of sands," Geotechnique, vol. 41, no. 3, pp. 365-381, 1991.

[20] J. H. Atkinson, An Introduction to the Mechanics Soils and Foundations: Through Critical State Soil Mechanis, McGraw-Hill, London, UK, 1993. 

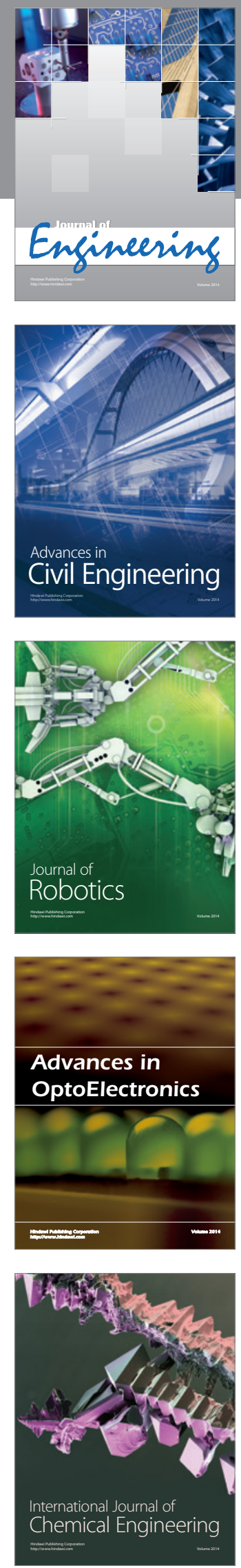

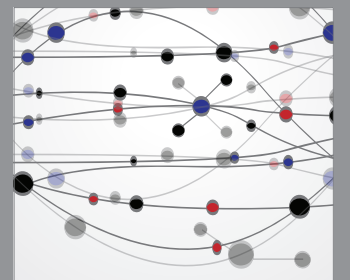

The Scientific World Journal
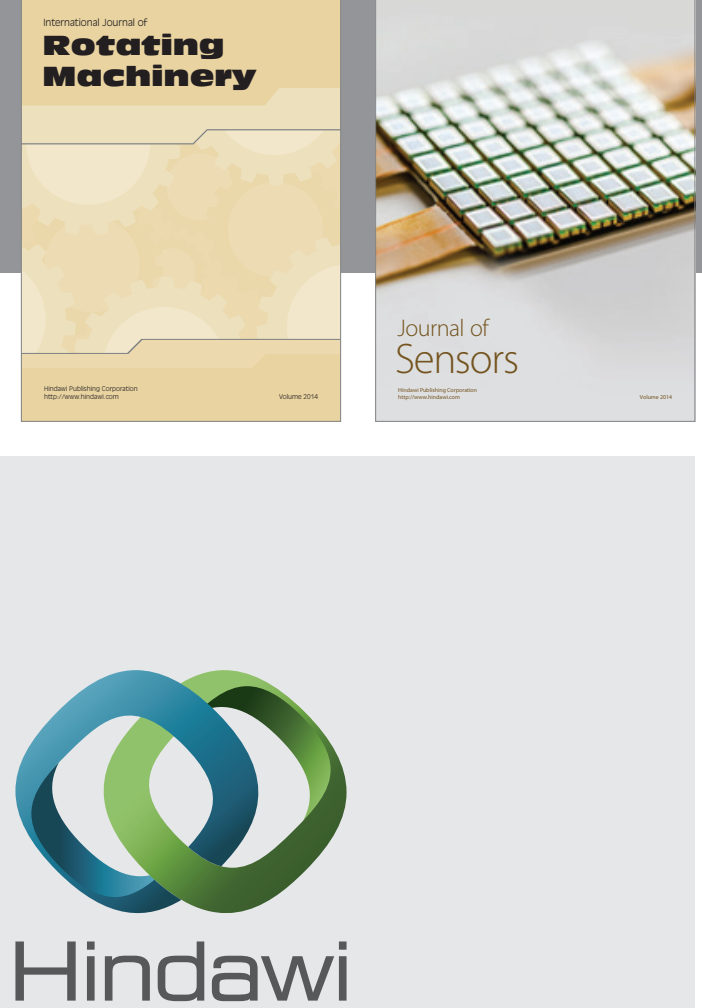

Submit your manuscripts at http://www.hindawi.com
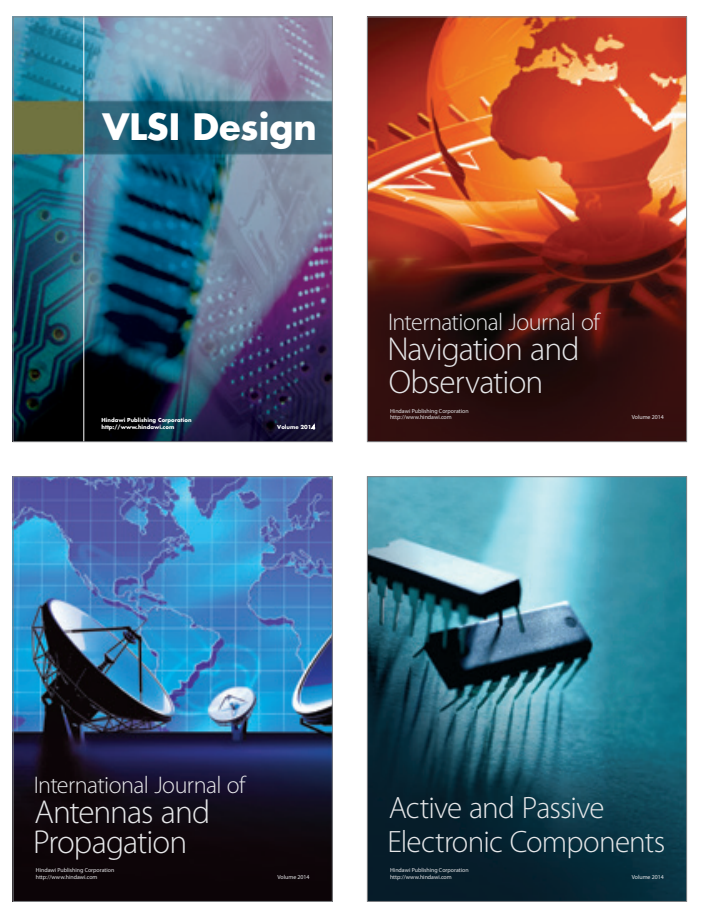
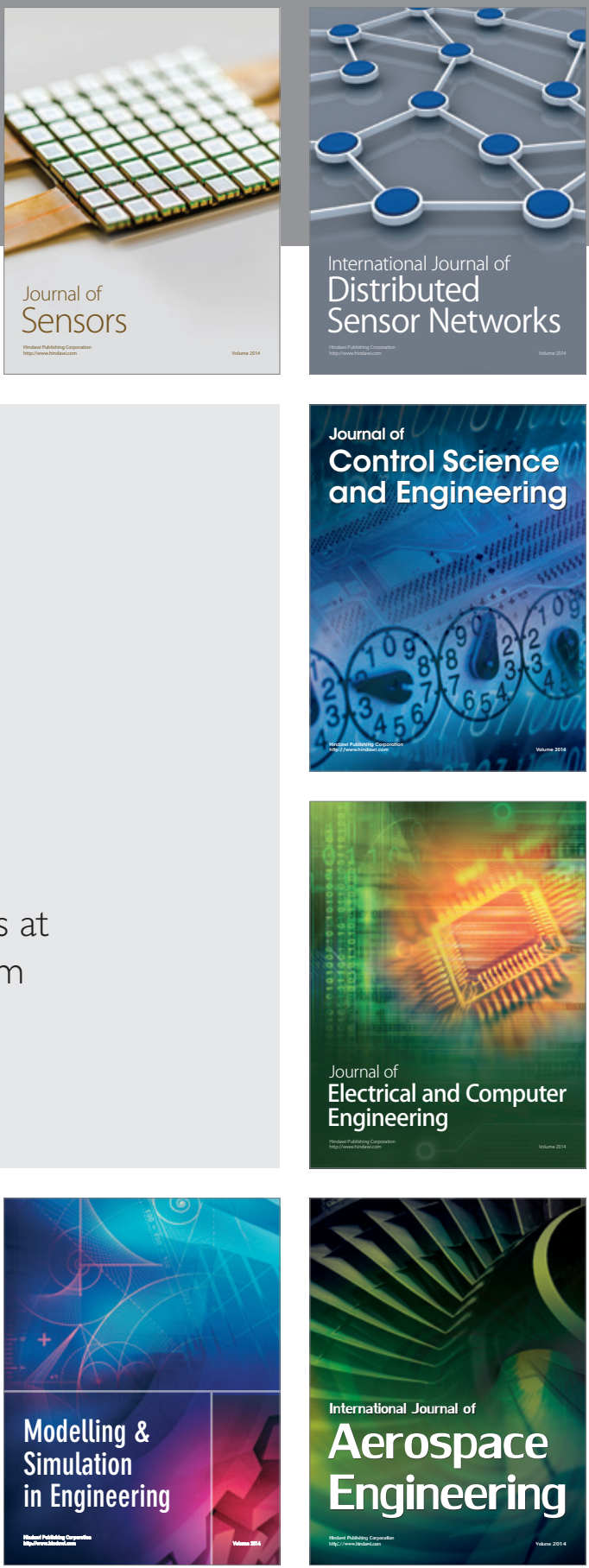

Journal of

Control Science

and Engineering
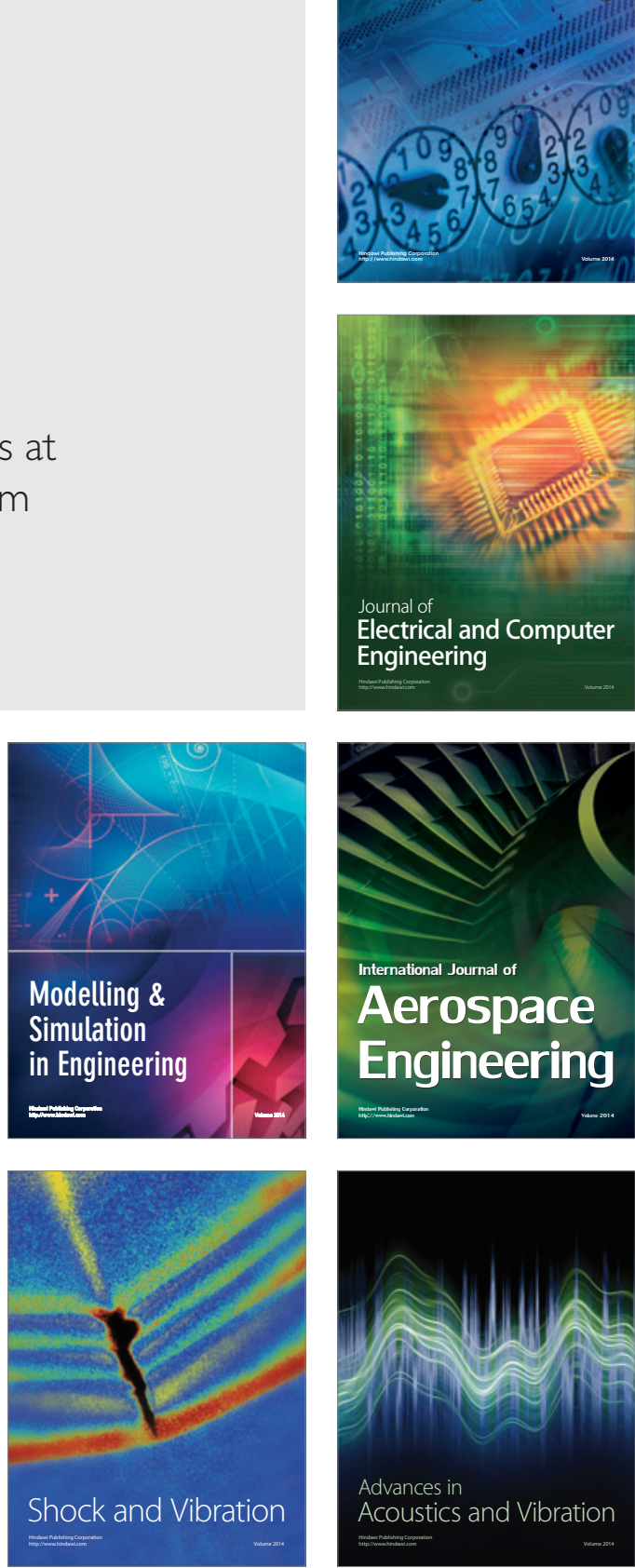